\title{
EM BUSCA DA
}

\section{RACIONALIDADEPERDIDA: alguns determinantes do voto no Distrito Federal ${ }^{*}$}

\section{Gláucio Ary Dillon Soares}

\section{Introdução}

Durante a ditadura, uma série de surveys eleitorais, feitos com a participação de vários dos mais destacados cientistas políticos brasileiros, revelou uma realidade preocupante: as avaliações das questões políticas nacionais mais prementes que caracterizaram aquele regime tinham correlações baixas umas com as outras e baixas ou modestas tanto com as preferências partidárias quanto com as intenções de voto. As avaliações dos serviços públicos e das políticas públicas que são características dos níveis estadual e municipal tinham correlações ainda mais baixas umas com as outras e também com com as preferências partidárias, assim como com as intenções de voto. Esses resultados geraram, entre os cientistas políticos e sociais brasileiros, várias indagações e uma preocupação: como o voto não estava ligado ao desempenho governamental, passava a ser desnecessário governar bem. Os diagnósticos e prognósticos eram sombrios porque

Trabalho apresentado na I Reunião da Associação Brasileira de Ciência Política, Rio de Janeiro, dezembro de 1998. O autor agradece os comentários de várias pessoas, inclusive de pareceristas anônimos da RBCS. sem cobrança não há accountability. Porém, para leigos, sobretudo de direita, esses resultados geraram certezas: o eleitor brasileiro era "irracional" e, se pudesse votar para presidente e governador, escolheria os mandatários a partir de critérios emotivos, irracionais, sendo presa fácil de qualquer demagogo de esquina. Pior, a cabeça do eleitor brasileiro seria um caos: ele não juntaria coisa com coisa. O eleitor seria pré-ideológico e a cultura política brasileira seria pré-cívica. Estas posições elitistas são antigas no Brasil e os dados das pesquisas eleitorais vieram reforçá-las, contra o ideário democrático dos pesquisadores.

Em 1978, no início da distensão, Bolivar Lamounier estudou as relações entre avaliações do desempenho governamental e preferência partidária no município de São Paulo, por nível educacional. Lamounier selecionou cinco áreas de avaliação (atendimento médico no INPS, custo de vida, casa própria através do $\mathrm{BNH}$, escola primária e policiamento) e quatro níveis educacionais (até primário completo, ginasial, colegial e superior), gerando vinte combinações possíveis. Os coeficientes de correlação (Phi) publicados pelo autor permitem observar o seguinte: dos vinte coeficientes, somente quatro foram significativos no nível 
de $5 \%$, dos quais três entre pessoas com educação superior. Somente um dos vinte coeficientes era superior a 0,3. A conclusão que se impõe é a de que as associações entre avaliações de políticas públicas e preferência partidária eram irrelevantes em todos os niveis educacionais, exceto o superior, no qual eram muito modestas, ainda que não irrelevantes.

Lamounier analisou, também, oito áreas de opiniões político-institucionais atribuídas aos candidatos e suas correlações com as preferências partidárias, pelos mesmos níveis educacionais. Das 32 correlações, somente três, relativas ao direito de greve, eram significativas no nível de $5 \%$ e nenhuma atingiu 0,3. Diferentemente das avaliações de políticas públicas, nenhuma correlação era significativa mesmo entre os entrevistados com educação superior. Estes resultados permitem concluir que $a$ percepção das posições político-institucionais dos candidatos era irrelevante para a preferência partidária, exceto a posição referente ao direito de greve. Seguindo as observações perspicazes de Fábio Wanderley Reis, examinei os dados relativos a nove "grandes questões" que foram pesquisadas por Lamounier. O exercício foi profícuo: das 36 correlações, 14 eram significativas a 5\% (mas 22 não o eram). Havia apenas dois coeficientes superiores a 0,5 ; somente quatro eram $\geq 0,4$ e seis eram maiores que 0,3. No que concerne às "grandes questões", os entrevistados com nível superior voltaram a ser mais consistentes. Uma questão que decerto nos preocupa, a afirmação de que "o povo sabe votar e normalmente escolhe os melhores candidatos", não se correlaciona com a preferência partidária em nenhum dos níveis educacionais.

O minucioso estudo de Lamounier permite concluir que:

- Durante a ditadura, a maioria das associações não era significativa no nível de $5 \%$ e $83 \%$ dos coeficientes eram inferiores a 0,3 ;

- Porém, levando em consideração o caráter frouxo dessas relações, a associação da preferência partidária com "as questões nacionais" era maior do que com a avaliação das políticas públicas, ou com a percepção das posições institucionais dos candidatos;
- Neste nível, as associações eram mais fortes entre as pessoas com educação universitária.

Algumas pesquisas realizadas após a redemocratização do país apresentaram resultados semelhantes aos encontrados na série conduzida durante o período ditatorial. Maria Judith de Brito Muszynski (1986), analisando as avaliações acerca de oito áreas de políticas públicas do governo do presidente José Sarney, verificou que apenas cinco delas tinham correlação estatisticamente significativa com a intenção de voto em Orestes Quércia, candidato ao governo de São Paulo nas eleições de 1986 pelo mesmo partido do presidente, o PMDB. ${ }^{1}$ As correlações eram baixas: a mais alta foi 0,26. Por sua vez, somente as avaliações referentes a duas áreas tinham correlações significativas com a intenção de voto no principal adversário de Quércia, Paulo Maluf. A aprovação do governador Franco Montoro tinha relação mais íntima com a intenção de voto no candidato do partido, Quércia, e, negativamente, no seu mais ferrenho opositor, Maluf. Quanto maior a aprovação, menor a percentagem preferindo Maluf. A aprovação do governador Montoro era mais relevante para a intenção de voto para governador do que a aprovação do presidente Sarney.

As avaliações não formaram conglomerados apertados; suas inter-relações eram frouxas. Além disso, nem o voto nem a preferência partidária dependiam essencialmente delas. $O$ seu poder de influenciá-los era pequeno. Destas constatações, alguns leram que a avaliação "global" do desempenho dos governantes e a intenção de voto independiam das avaliações das políticas públicas. Por sua vez, a quase ortogonalidade da avaliação dos executivos e da intenção de voto para cargos executivos em relação às avaliações dessa ou daquela política pública era, para alguns, mais uma evidência - mais do que suficiente — de que "o brasileiro não sabe votar". 2 A avaliação das políticas públicas teria nada ou pouco a ver com a intenção de voto e, por conseqüência, com a eleição ou reeleição.

Hélgio Trindade e Judson de Cew, em survey realizado em 1976, referente a Caxias do Sul (RS), concluíram que a identificação partidária era a 
única variável relevante para a intenção de voto: as avaliações a respeito do custo de vida, sobre os problemas econômico-sociais, a opinião sobre os governos e a ideologia tinham influência muito pequena (Trindade e Cew, 1978).

Porém, Fábio Wanderley Reis (1978) já havia qualificado esta relação num estudo realizado em 1976 em Juiz de Fora (MG). Analisando a preferência partidária (e não a intenção de voto), ele concluiu que as "grandes questões" político-institucionais da época (voto direto, voto do analfabeto, AI-5, política salarial, Lei Falcão etc.) tinham uma correlação razoável com a preferência partidária, sobretudo no nível de renda mais alto (mais de oito salários mínimos). A observação da Tabela IX de seu estudo mostra que, abaixo deste nível de renda, nenhum coeficiente de correlação $(P h i)$ atingiu 0,30. Fábio Wanderley Reis demonstrou, também, que as correlações entre o que ele chamou de "questões locais" (atendimento médico, escola primária, transporte coletivo etc.) e a preferência partidária eram mais baixas (somente uma entre 32 correlações supera 0,19), inclusive no nível de renda mais alto (de mais de oito salários mínimos). A Tabela XI do mesmo estudo indica que o nível de renda não se relacionava com a magnitude das correlações. A contribuição de Reis se encaixa bem com os resultados das pesquisas relatadas por Lamounier, Muszynski e Trindade e Cew.

Os resultados empíricos dos estudos citados acima não foram trabalhados com o objetivo de elaborar uma teoria. Não obstante, se os autores das pesquisas assim o quisessem, eles se encaixariam bem nos preconceitos da elite e de grupos autoritários, que se cansaram de afirmar que "O povo [brasileiro] não sabe votar". Durante a ditadura, a afirmação tinha uma conveniente dimensão temporal: "o povo brasileiro ainda não está preparado para a democracia" (ou para eleger o presidente, os governadores etc.).

Porém, a perplexidade que a modéstia das correlações gerou foi artificialmente aumentada pela não incorporação de alguns fatores nas formulações teóricas e na análise dos dados:

- as correlações de intervalo obtidas em surveys de atitudes, crenças e opiniões são mais baixas do que as correlações entre variáveis agregadas. Isto se demonstra com a mesma base de dados, usando as mesmas variáveis, nos níveis individual, municipal e estadual: a média dos coeficientes de correlação aumenta com o nível de agregação;

- as inter-relações entre as várias avaliações são também modestas. Portanto, nenhuma avaliação de uma política pública específica representa adequadamente o conjunto das avaliações;

- empiricamente, os indices com freqüência têm poder preditivo substancialmente maior do que os indicadores - no caso, representados pelas avaliações de políticas públicas individualizadas;

- quando a eleição inclui um partido/executivo que governa ou governou e outro que não o fez, a comparação é entre um conjunto de observáveis e um conjunto de não-observáveis.

Aproveitando a circunstância de que os dois principais pré-candidatos a governador do Distrito Federal $^{3}$ (definidos pelas intenções de voto no momento da pesquisa) eram um ex-governador, Joaquim Roriz, e um governador, Cristovam Buarque, foi possível fazer uma avaliação comparativa de politicas públicas entre dois conjuntos de observáveis.

\section{Questões de método}

Os dados

Esta é uma análise de dados secundários. Os dados foram coletados pelo Núcleo de Pesquisas da Codeplan, em fins de 1997 e início de 1998, através de amostra domiciliar aleatória estratificada por região administrativa e por nivel de consumo de energia, com base na lista de consumidores. ${ }^{4}$ Os dados foram analisados usando as ponderações da amostra. Foi entrevistada somente a população que declarou ter título de eleitor registrado no Distrito Federal. $^{5}$ Foram aproveitadas 5.239 entrevistas.

A construção de escalas

Todos os itens foram formulados de acordo com o seguinte formato: 
Qual o governador que mais fez (pela segurança pública etc.) no Distrito Federal?

1 - Cristovam Buarque

2 - Joaquim Roriz

3 - Nenhum desses

4 - Não sabe

5 - Sem resposta

Um dos itens — "Em que governo houve mais corrupção?” — não incluiu a opção "nenhum desses". O fato de que esse item tenha tido uma saturação mais baixa no fator geral pode indicar que uma parcela significativa da população teria outro governador em mente.

Partí do princípio de que várias políticas públicas proporcionariam um mapa substancialmente mais adequado das avaliações comparativas do desempenho dos governadores nessa área do que uma ou duas. Usei, então, duas técnicas consagradas de construção de escalas: escalas somatórias e escores fatoriais. Recodifiquei as avaliações buscando a ordinalidade das respostas, baseado na polarização entre Cristovam e Roriz, sendo os valores $1=$ Cristovam; $2=$ Outras respostas e 3=Roriz. A ordinalidade, não obstante, é discutível, pois se baseia na polarização entre Cristovam e Roriz, uma observação apoiada pelo fato de que poucos entre os que pretendiam votar em um dos dois exgovernadores votariam no outro caso o candidato preferido não chegasse ao segundo turno, privilegiando o senador Arruda (o terceiro pré-candidato) ou anulando o voto, votando em branco ou se abstendo, ao passo que os que preferiam Arruda se dividiriam entre os dois principais opositores. ${ }^{6}$

No índice somatório, adicionei os valores correspondentes a dez avaliações, atribuindo peso igual a todas. O índice, portanto, variava de 10 (o maior valor pró-Cristovam e menor pró-Roriz) a 30 (menor valor pró-Cristovam e maior pró-Roriz). Reduzí o número de categorias com base sobretudo nas freqüências marginais, juntando categorias com baixa freqüência, e no poder de diferenciação. Categorias adjacentes com distribuições semelhantes da intenção de voto foram juntadas. Agreguei as duas primeiras (as mais pró-Cristovam), as duas seguintes e as cinco últimas (as mais pró-Roriz), renumerando-as de 1 a 14 . Para verificar se estas avaliações se estruturam com outras dimensões da psicologia política do eleitor brasiliense, tabulei os escores neste índice somatório de avaliação comparada do desempenho dos governadores com outras variáveis, tomadas como dependentes.

$\mathrm{Na}$ análise fatorial, usei a solução dos componentes principais, sem rotação, tomando um eigenvalue de 1 como limite para a extração de um fator. Houve, como esperado, um forte fator geral, no qual todas as avaliações têm saturações satisfatórias, variando de -0,45 (Corrupção, a única formulada negativamente) a 0,707 (Segurança) ao longo do eixo Cristovam-Roriz, e um fator claramente secundário (cujo eigenvalue, de 1,334, contrasta com o do primeiro componente, de 4,271), cuja saturação mais elevada corresponde à avaliação das políticas relativas ao trânsito.

\section{Tabela 1}

Comunalidade das avaliações de políticas públicas específicas

\begin{tabular}{lcc}
\hline Variáveis & Inicial & Extração* $^{*}$ \\
\hline Corrupção & 1,000 &, 202 \\
Educação & 1,000 &, 597 \\
Segurança & 1,000 &, 558 \\
Trânsito & 1,000 &, 707 \\
Transportes & 1,000 &, 557 \\
Habitação & 1,000 &, 564 \\
Saneamento urbano & 1,000 &, 482 \\
Fez mais pelo metrô & 1,000 &, 437 \\
Próximo do povo & 1,000 &, 535 \\
Funcionários públicos & 1,000 &, 451 \\
Gerou empregos & 1,000 &, 516 \\
\hline
\end{tabular}

* Extração pelo método dos componentes principais.

1 Esta avaliação obedecia um formato diferente, o que confirma que a forma das perguntas ou quesitos influencia as correlações entre elas.

2 Este quesito não se referia a uma política pública, mas a uma imagem pública. Respondia à percepção de Roriz como "próximo do povo" e de Cristovam como um intelectual "distante do povo".

A comunalidade das avaliações das políticas específicas é muito variável. A corrupção, talvez por ter um formato diferente, apresentou, como esperado, uma comunalidade mais baixa. Excluindo a corrupção, a comunalidade varia de 0,44 a 0,71 , 
aproximadamente. Isto nos diz que percentagem da variância de cada item está na matriz e que percentagem está fora dela. Aproximadamente a metade da variância das avaliações específicas pode ser explicada com dois fatores.

Tabela 2

Percentagem da variância total explicada por cada componente*

\begin{tabular}{|c|c|c|c|c|}
\hline \multicolumn{5}{|c|}{$\begin{array}{l}\text { Eigenvalues } \\
\text { Iniciais }\end{array}$} \\
\hline Componente & Total & \% da variância & $\%$ & acumulada \\
\hline 1 & 4,271 & 38,830 & & 38,830 \\
\hline 2 & 1,334 & 12,124 & & 50,954 \\
\hline 3 & ,873 & 7,940 & & 58,895 \\
\hline 4 & ,793 & 7,212 & & 66,107 \\
\hline 5 & 629 & 5,715 & & 71,822 \\
\hline 6 & ,608 & 5,523 & & 77,346 \\
\hline 7 &, 571 & 5,191 & & 82,537 \\
\hline 8 &, 546 & 4,964 & & 87,501 \\
\hline 9 & ,483 & 4,393 & & 91,893 \\
\hline 10 & 460 & 4,178 & & 96,072 \\
\hline 11 & , 432 & 3,928 & & 100,000 \\
\hline
\end{tabular}

* Extração pelo método dos componentes principais. A área cinza marca os componentes aceitos com base no eigenvalue.

A análise da matriz dos componentes nos mostra que o primeiro fator é claramente um fator geral de avaliação, no qual pesam todas as políticas. Segurança pública é a que tem mais alta saturação, mas várias políticas estão entre 0,6 e 0,7. Já o Fator 2 opõe as políticas de trânsito — talvez o maior êxito da administração de Cristovam Buarque - às de habitação - talvez o maior êxito da administração Roriz, implementadas mediante a política de distribuição de lotes.

No que concerne à variável dependente intenção de voto, como a ordinalidade também é discutível, em algumas análises recodifiquei os dados, incluindo somente as preferências por Cristovam e outras respostas, Roriz e outras respostas etc. As respostas dicotômicas puderam ser analisadas usando uma regressão logística binomial, ao passo que as com mais de duas respostas categóricas foram analisadas usando uma regressão logística multinomial.
Tabela 3

Matriz dos componentes principais*

\begin{tabular}{lcc}
\hline & \multicolumn{2}{c}{ Componentes } \\
\cline { 2 - 3 } & \multicolumn{1}{c}{1} & \multicolumn{1}{c}{2} \\
\hline Corrupção &,- 450 & -6.337 E-03 \\
Educação &, 627 &,- 452 \\
Segurança &, 707 &,- 241 \\
Trânsito &, 540 &,- 644 \\
Transportes &, 688 &,- 290 \\
Habitação &, 564 &, 496 \\
Saneamento urbano &, 693 & 3.167 E-02 \\
Metrô &, 562 &, 347 \\
Amigo do povo &, 659 &, 317 \\
Funcionários públicos &, 619 &, 262 \\
Emprego e renda &, 693 &, 188 \\
\hline
\end{tabular}

* Extração pelo método dos componentes principais. Foram extraídos dois componentes.

\section{O "enigma" da aprovação maior do que a intenção de voto}

Um dos freqüentes "enigmas" gerados pelas pesquisas eleitorais é a disparidade entre a alta aprovação de alguns governantes e a intenção de voto moderada pela sua reeleição. ${ }^{7}$ Em Brasília, consistentemente, diferentes pesquisas realizadas por várias agências concluíram que a percentagem que aprovava o governo de Cristovam Buarque era maior que a que pretendia votar nele. O mesmo ocorria em outros estados, como Minas Gerais. No Distrito Federal, a diferença chegou, em algumas pesquisas, a mais de 30 pontos percentuais.

O "enigma", contudo, não tem razão de ser: a aprovação/desaprovação de um governo não compara dois ou mais candidatos. É uma nota dada de acordo com critérios internos a cada um. No caso de Cristovam Buarque, a nota era alta. Porém, a intenção de voto reflete uma escolha entre candidatos. Numa hipotética escolha entre quatro ex-governadores, todos poderiam ter boas avaliações (oxalá fosse sempre assim em todo o Brasil); não obstante, somente um poderia ser o escolhido. O primeiro instrumento mede se a população pensa que o governador é bom; o segundo mede se ela pensa que ele é o melhor candidato, o que acarreta uma comparação com outros. 


\section{O mito da irracionalidade}

Essas falsas inconsistências levaram alguns analistas a aplicar, ao Distrito Federal e a vários outros estados, mais uma vez, a velha e errônea acusação de que "o brasileiro não sabe votar". Esta acusação, de tanto repetida, virou um mito e um segmento importante da própria população acredita nele: diferentes surveys, feitos com anos de diferença, mostram que parte substancial da população concorda com esta afirmação de que "o povo não sabe votar". Lúcia Avelar (1989), analisando dados relativos a 1982, controlou os resultados por idade, escolaridade e sexo (subdividindo as mulheres em profissionais e donas de casa), mostrando que, em oito áreas metropolitanas, os que acreditavam que o povo não sabe votar representavam entre um terço e dois terços da população, dependendo do subgrupo. Não é uma peculiaridade local nem de gênero: entre estudantes do Rio Grande do Norte, nada menos do que 56,5\% eram contrários ao voto dos analfabetos (Ferreira e Sousa, 1996, p. 152).

Moisés (1993) informa que em 1972 e em 1982, somente $50 \%$ e $47 \%$ dos brasileiros, respectivamente, concordavam com a afirmação de que "o povo sabe votar". No que concerne ao voto dos analfabetos, em 1972, um ano de chumbo, somente $38 \%$ o favoreciam; dez anos depois, com a distensão e a mudança na estrutura partidária, essa percentagem subiria para $60 \%$. O apoio ao voto dos analfabetos manteve-se aproximadamente neste nível em 1989 e 1990. Estes dados mostram o efeito da ditadura sobre a fidedignidade das respostas a surveys de opinião $e$ sobre as crenças democráticas, sendo impossível determinar onde começa uma e termina outra. Em outro quadro, Moisés nos fornece séries cobrindo o período de 1978 a 1990 nas quais a percentagem contrária ao voto dos analfabetos varia entre $31 \%$ e $44 \%$.

Uma vertente da "teoria" de que o brasileiro não sabe votar inverte a relação entre avaliação do desempenho das políticas públicas e intenção de voto. ${ }^{8}$ De acordo com ela, os eleitores desenvolveriam atitudes positivas ou negativas em relação aos partidos e candidatos e, a partir delas, avaliariam positiva ou negativamente as políticas públicas do governo em pauta. Paradoxalmente, isso implicaria alguns padrões opostos aos vistos anteriormente:

- as correlações entre avaliações de políticas públicas específicas, por um lado, e as preferências partidárias e/ou intenção de voto, por outro, seriam sempre altas;

- as freqüências marginais das várias avaliações seriam semelhantes, ou teriam pouca variância entre si: quem apoiasse um partido ou candidato, apoiaria também todas ou quase todas as políticas públicas implantadas; quem rejeitasse o partido ou candidato, faria o mesmo com as políticas públicas implementadas ou propostas por eles;

- as correlações entre as várias avaliações das políticas públicas, que seriam simples reflexos das preferências por partido/candidato, seriam também muito altas, formando blocos, conglomerados excepcionalmente apertados;

- os ganhos marginais na explicação da variância da intenção de voto através da construção de indices compostos, em comparação com indicadores simples, seriam pequenos, dado que grande parte da variância de cada avaliação seria comum às outras avaliações.

Porém, em todas as pesquisas cujos dados foram publicados encontramos variações significativas entre as várias avaliações. A pesquisa eleitoral conduzida por Bolivar Lamounier em 1976 produziu resultados semelhantes: analisando os dados de Presidente Prudente (SP), Lamounier (1978) mostrou uma variação no desempenho governamental que vai de $75 \%$ de respostas "muito bom", no que se referia à escola, a $6 \%$ delas no que se referia ao custo de vida. No que concerne aos serviços municipais, a aprovação ("ótimo") variava de $61 \%$, no que dizia respeito à escola primária, a $55 \%$ e 54\%, com relação, respectivamente, à água e ao transporte coletivo, e a $21 \%$ no que se referia à conservação das ruas. Em Niterói, Olavo Brasil de Lima Jr. (1978) relatou um nível muito mais baixo de satisfação com os serviços municipais, variando de $32 \%$ (transporte coletivo) a $8 \%$ (esgoto) e $9 \%$ (conservação das ruas). Comparando os mesmos itens em populações diferentes, verificamos que há muita variância entre elas. 
A passagem da democracia com participação restrita à democracia com participação ampliada depende da aceitação de que "os outros" sabem votar. Seja na sua versão ampla (o povo, os brasileiros), seja na sua versão limitada e focalizada (os analfabetos, os que não foram à escola), a rejeição do voto universal é uma posição classista e preconceituosa, perigosa para a democracia. O direito de votar foi negado a dezenas de milhões de brasileiros até 1988 com base numa variante dela, de tipo vagamente iluminista, que vincula o "acerto" do voto com a educação formal. Daí a necessidade de desfazer esse mito.

\section{Análise}

\section{As avaliações são diferenciadas, não são \\ "em bloco"}

Este trabalho usa dados de recente pesquisa de opinião para afastar alguns destes mitos e elucidar alguns enigmas sobre a política brasileira, tomando as eleições de 1998 para governador do Distrito Federal como exemplo. É parte integrante de uma série de pesquisas que pretende combater os mitos da irracionalidade e da imprevisibilidade do eleitor brasileiro. Como as pesquisas mencionadas demonstraram pequenas ou modestas correlações entre a avaliação das políticas públicas, por um lado, e a avaliação do desempenho do governante, a preferência partidária e/ou a intenção de voto, por outro, é contra este pano de fundo empírico que o artigo foi escrito.

Os dados relativos ao Distrito Federal mostram que os eleitores também diferenciam entre programas e atributos dos governadores, atuais e passados. Contrariamente à ideologia elitista e vanguardista que afirma, contra um mar de dados e de evidências, que os eleitores brasileiros não sabem votar e engolem tudo o que lhes é dito, os dados demonstram que os mesmos eleitores conferem aos dois candidatos altas percentagens em alguns itens e baixas em outros. Eles diferenciam entre uma política pública e outra. Os eleitores não avaliam "em bloco" em favor de um candidato, ou seja, não avaliam todas as áreas com intensidade semelhante, tendência que seria característica de eleitores pouco seletivos, do tipo "fecho, não abro e não quero saber". Em sua maioria, os eleitores do Distrito Federal não são assim. De um lado, 66\% acham que Cristovam é o governador que mais fez pela paz no trânsito, mas somente $11 \%$ acham que ele é o que mais fez pelos funcionários públicos; do outro lado, 53\% acham que Roriz é quem mais fez pela habitação, em contraste com $9 \%$ que acham que ele é o que mais fez pelo trânsito. Há áreas, como habitação, educação e trânsito, nas quais a grande maioria dos eleitores se define por um ou outro candidato, mas em outras, como emprego e renda, funcionários públicos e segurança pública, a população não parece estar satisfeita com nenhum dos dois governadores, abrindo espaço para outros candidatos. Os dados não ponderados nos dão as seguintes distribuições (Tabela 4):

Tabela 4

Os eleitores diferenciam entre as políticas públicas dos governadores

\begin{tabular}{lrccc}
\hline $\begin{array}{l}\text { Área de política } \\
\text { pública }\end{array}$ & \multicolumn{3}{c}{ Quem fez mais } & nesta \\
área & pelo & Distrito & Federal? \\
\hline & Roriz & Cristovam & $\begin{array}{c}\text { Outras } \\
\text { respostas }\end{array}$ \\
Violência no trânsito & $9 \%$ & $66 \%$ & $25 \%$ \\
Educação & $25 \%$ & $49 \%$ & $34 \%$ \\
Transporte público & $17 \%$ & $33 \%$ & $50 \%$ \\
Saneamento básico & $25 \%$ & $31 \%$ & $44 \%$ \\
e urbanização & & & \\
Segurança pública & $20 \%$ & $30 \%$ & $50 \%$ \\
Metrô & $44 \%$ & $18 \%$ & $38 \%$ \\
Emprego e renda & $20 \%$ & $14 \%$ & $66 \%$ \\
Habitação & $53 \%$ & $13 \%$ & $34 \%$ \\
Funcionários públicos & $22 \%$ & $11 \%$ & $67 \%$ \\
\hline
\end{tabular}

Os dados da pesquisa no Distrito Federal sugerem que os eleitores analisam e avaliam os candidatos (no momento da pesquisa, pré-candidatos, ainda não oficialmente lançados) a partir de uma plataforma diversificada. ${ }^{9}$ Assim, muitos partidários de Cristovam pareciam crer que as eleições estavam ganhas devido ao sucesso do governador na pacificação do trânsito e na área da educação. Perceberam que estes eram os itens que mais favoreciam Cristovam nas comparações do desem- 
penho governamental e centraram neles a campanha eleitoral. A população respondeu bem a essa campanha do GDP (Governo Democrático e Popular): $66 \%$ dos entrevistados afirmaram que o desempenho de Cristovam na educação e no controle do trânsito foi superior ao de Roriz, 25\% achavam que nenhum dos dois foi o melhor ou deram outras respostas, e somente 9\% acharam que o de Roriz foi superior. A bolsa-escola ainda hoje é um dos programas mais populares do GDP, tendo merecido citações internacionais. ${ }^{10} \mathrm{~A}$ partir destes dados, e somente destes dados, o leitor desavisado poderia concluir que a intenção de voto favoreceria Cristovam. Errado. Embora cada governo tenha ênfases próprias, foram poucos os casos em que uma política pública, isoladamente, garantiu uma reeleição. O trânsito é uma das dimensões nas quais a intenção de voto se alicerça. A educação é apenas outra. Há muitas mais. Assim, 46\% dos que achavam que Cristovam foi o governador que mais fez para diminuir a violência no trânsito não votariam nele naquele momento: 29\% votariam em Roriz, 13\% em Arruda e 4\% em Augusto Carvalho. ${ }^{11}$ Uma política pública acertada pode ajudar muito, mas raramente define o resultado de uma eleição.

O mesmo se aplica a Roriz ou a quaisquer outros governadores. Roriz é popular devido à distribuição de lotes e à sua imagem de "próximo ao povo". Significa isto que teria vitória garantida nas eleições, caso o quadro pré-eleitoral se mantivesse? Também não. Objetivamente, Roriz distribuiu mais lotes que qualquer governador. Isto lhe granjeou apoio entre os que receberam lotes, seus familiares e amigos. Provocou, talvez, simpatias entre os que aspiravam receber um lote. Inicialmente, a política de distribuição de lotes era o sonho de qualquer político: afastava "invasores"12 considerados incômodos e/ou perigosos pelos residentes de áreas de classe alta, média ou trabalhadora estabelecida e os transferia para áreas distantes, dando-lhes lotes. Agradou a todos. Posteriormente, porém, esta política passou a ser questionada, tendo em vista a criminalidade violenta que caracteriza estas áreas e a alta taxa de crescimento demográfico de vários destes assentamentos. Setenta e quatro porcento dos entrevistados concordavam que a distribuição de lotes feita por Roriz atraiu imigrantes. Eleitoralmente, Roriz arrazou entre a minoria que achava que os assentamentos não atraíram migrantes internos: 60\%, em claro contraste com $31 \%$ entre os que acreditavam que atraíram. Os demais pré-candidatos cresceram entre os que acreditavam que a distribuição de lotes atraiu imigrantes: Cristovam, de $11 \%$ para 24\%; Arruda, de $6 \%$ para $14 \%$, e Augusto Carvalho, de $1 \%$ para $4 \%$. A opinião pública a respeito da criação de novos assentamentos também se modificou com o tempo. Se, há poucos anos, a população era avassaladoramente favorável à medida, na época da coleta de dados para esta pesquisa a proposta era apoiada por somente $42 \%$ dos entrevistados. Entre os que apoiavam a criação de novos assentamentos, Roriz recebia $45 \%$ das preferências; entre os que não apoiavam, a percentagem caía para $23 \%$. Os demais pré-candidatos, ao contrário, subiram: Cristovam, de $19 \%$ para 27\%; Arruda, de 9\% para $16 \%$ e Augusto Carvalho, de $2 \%$ para $5 \%$. A política de distribuição de lotes foi, assim, um dos temas centrais da campanha eleitoral, devido à sua alta correlação com a intenção de voto.

A terceira coluna da Tabela 4 refere-se à percentagem dos que acreditavam que quem mais fez naquela área não foi nem Cristovam, nem Roriz. A percentagem não é uniforme, variando de $25 \%$, no trânsito, a $66 \%$ e $67 \%$ (ou dois em três) no que concerne, respectivamente, à geração de emprego e renda e ao apoio aos funcionários públicos. Esta variação significa que a população distribuiu as políticas públicas em três categorias: aquelas em que o desempenho de Cristovam foi melhor; aquelas em que o desempenho de Roriz foi melhor e aquelas em que o melhor desempenho não foi nem de um, nem de outro, mas de outros ex-governadores do Distrito Federal.

A pesquisa, porém, revelou algo mais: a população brasiliense tem um alto grau de coerência entre a avaliação das políticas públicas e a intenção de voto, contrariando as descobertas das pesquisas pioneiras nesta área. Quando usamos cumulativamente as avaliações comparadas em dez setores de atividade governamental, a relação é muito estreita. Comecemos pela relação entre o índice somatório de avaliação do desempenho em políticas públicas e a intenção de voto para os quatro pré-candidatos. 

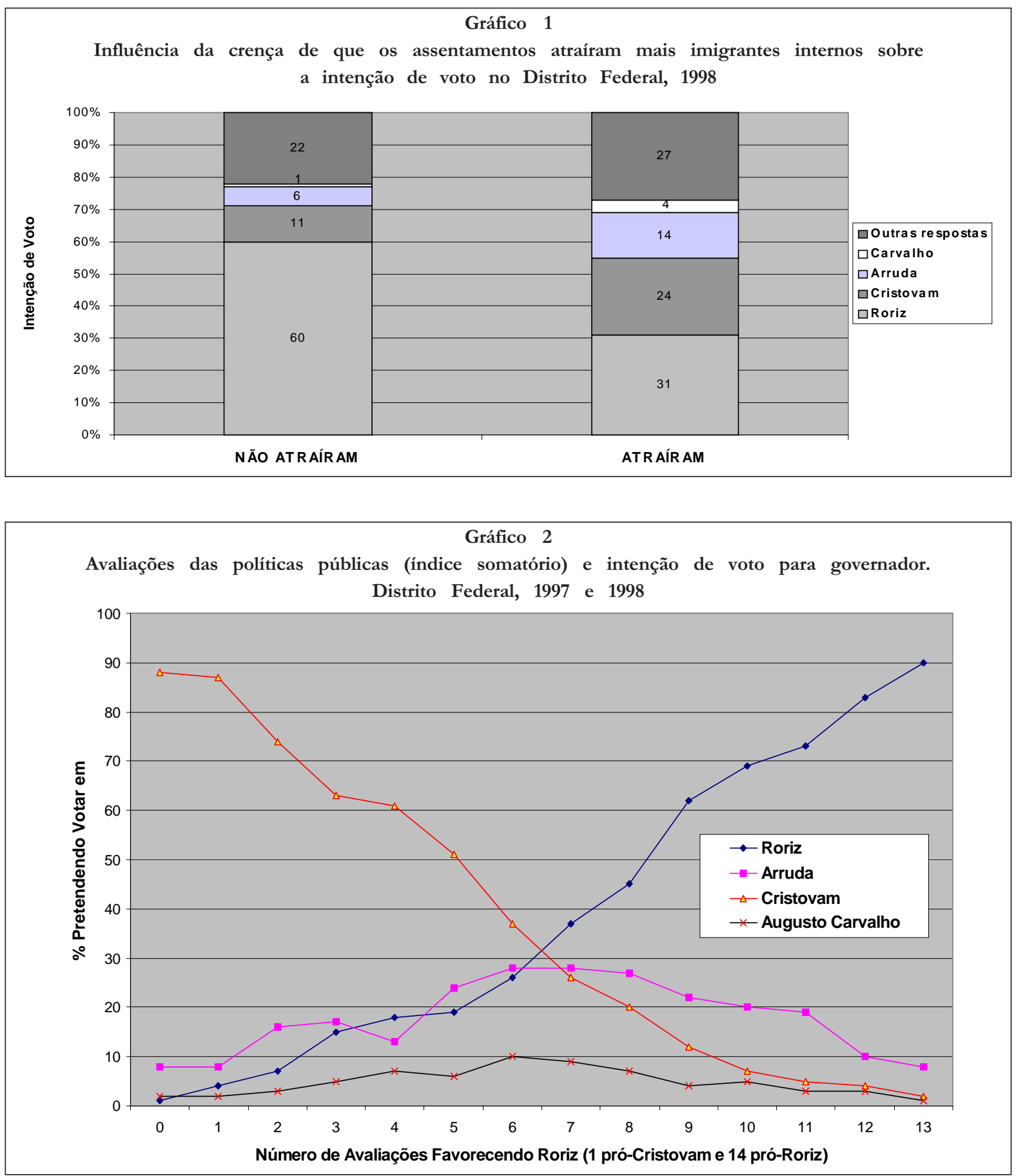

O Gráfico 2 mostra que a avaliação cumulativa das políticas públicas tem uma relação clara e definida com a intenção de voto. Mostra, também, que as distribuições estão longe de ser aleatórias. Há clara tendência decrescente na intenção de voto para
Cristovam a cada aumento no escore do índice somatório e uma clara tendência crescente na intenção de voto para Roriz. Não é o que seria de esperar se a "teoria"13 de que os brasileiros votam na base de apelos pessoais de cunho irracional 
fosse válida, nem se os eleitores respondessem apenas ao carisma do candidato, ${ }^{14}$ de forma irracional, sem base avaliativa. Se não relacionassem as políticas públicas ao voto, não haveria associação entre as avaliações e a intenção de voto; se os eleitores respondessem somente a apelos emocionais do candidato preferido, quase todos avaliariam melhor as políticas públicas implementadas por esse candidato.

As intenções de voto para Arruda e Carvalho obedeciam a uma equação curvilinear, como seria de esperar quando aceitamos que as "outras respostas" (nem Cristovam, nem Roriz) indicariam maior disponibilidade a aceitar terceiros candidatos. Talvez alguns argumentem que isso é "intuitivo", 15 mas poderá sê-lo somente a partir do momento em que se aceitar que há uma relação entre avaliações das políticas públicas e intenção de voto. Quem não aceitar essa relação, para ser consistente, deverá defender uma distribuição aleatória das preferências em cada intervalo da escala, reproduzindo a distribuição total de freqüência das intenções de voto. Não é possível defender que o voto responde ao "carisma" do candidato, sem relação com as características dos eleitores e seus interesses. ${ }^{16}$

Continuemos com a intenção de voto para Roriz. O R $\mathrm{R}^{2}$, baseado no coeficiente de Pearson linear, é de $0,97 .^{17}$ Tanto a inspeção visual quanto a magnitude do coeficiente de determinação não deixam dúvida sobre quão íntima é a relação entre o índice de desempenho e a intenção de voto para Roriz. A intimidade desta relação não é captada na sua totalidade por quesitos (avaliações) individualizados que, embora correlacionados com a intenção de voto, apresentam amplos erros de especificação. Este é um ponto importante: os que relacionaram avaliações individualizadas, por um lado, e intenção de voto ou preferência partidária, por outro, encontraram relações fracas ou modestas. Mas a avaliação do desempenho das políticas públicas de um governo é multidimensional. As relações simples, bivariatas, tomando um serviço público de cada vez, deixam de fora as demais dimensões do desempenho de um governante e, conseqüentemente, apresentam um erro de especificação bem maior.

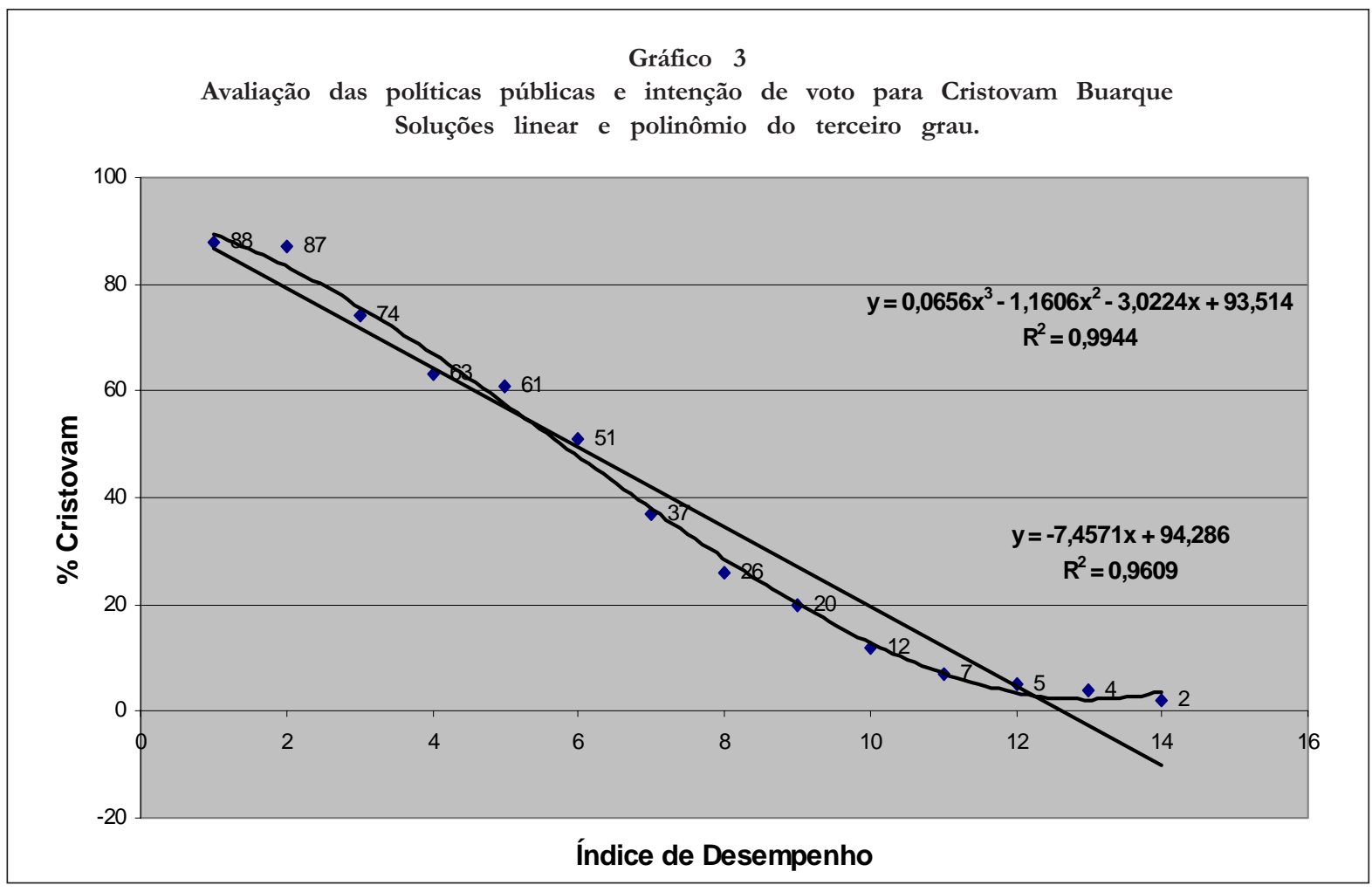


Como seria de esperar, a relação entre o índice de desempenho e a intenção de voto para Cristovam é igualmente clara, mas negativa, uma vez que o índice foi feito na direção de "a maior valor, pior a avaliação das políticas públicas de Cristovam". Aqui, também, a solução polinomial proporciona valores muito altos, mas a linear é mais do que satisfatória. ${ }^{18}$

A relação entre a avaliação comparada do desempenho dos governadores e a intenção de voto parece intuitiva: afinal, espera-se que quem avalia o desempenho de um governador em várias políticas públicas como sendo o melhor esteja mais disposto a votar nele. Entretanto, esta relação no DF apresenta-se muito mais intensa do que a encontrada em pesquisas anteriores feitas no Brasil. Os gráficos mostram que tanto as percentagens, sobre o total das intenções de voto, por Cristovam quanto as percentagens por Roriz, nos 14 valores de avaliação do desempenho, podem ser explicadas satisfatoriamente por uma solução linear. ${ }^{19}$

A relação entre o valor no índice somatório que representa o eixo Cristovam-Roriz e a intenção de voto para Arruda e Carvalho (cujas políticas públicas - como diferente de suas propostas para elas - não foram avaliadas porque eles não foram governadores) é claramente curvilinear, sendo bem descrita por um polinômio de segundo grau. O coeficiente de determinação $\left(R^{2}\right)$ é de 0,82 com Arruda e 0,77 com Carvalho. A curvilinearidade era esperada: afinal, as avaliações consistentemente positivas de Cristovam se concentram num dos extremos da escala e as de Roriz, no outro. Aritmeticamente, quem achava que nem Cristovam nem Roriz foi quem mais fez por tal ou qual política pública concentrou-se no meio da distribuição do índice. Nos valores 7, 8 e 9 (a escala varia de 1 a 14) Arruda atingia mais de $25 \%$ das preferências; Carvalho obtinha mais de $8 \%$ nos níveis 7 e 8 . Acima e abaixo destes limites, as percentagens preferindo esses dois candidatos diminuíam.

A conclusão é a de que, no Distrito Federal, a intenção de voto para um ex-governante é função da avaliação de um conjunto de políticas públicas. Se os determinantes "últimos" forem outros, eles passam pelas avaliações das políticas públicas.
Porém, este resultado é a exceção na história das pesquisas eleitorais brasileiras. Von Mettenheim (1995), analisando dados de pesquisa de 1982 obtidos no Sudeste e no Nordeste, mostrou que uma escala de atitudes em relação a temas nacionais influenciava consideravelmente a intenção de voto para governador (Beta de 0,39 e acréscimo de 0,15 ao $R^{2}$, mas que escala semelhante referente a temas locais (mais semelhantes aos usados no Distrito Federal) acrescentava muito pouco (Beta de 0,06 e nenhuma melhoria no $R^{2}$ ). Os resultados levaram von Mettenheim (1995, p. 164) a afirmar que "a posição em relação a políticas públicas locais nas amostras urbanas do Sudeste e do Nordeste permanece sem relação com a escolha dos eleitores".

Esta conclusão é a única que os dados sobre as eleições de 1974, 1978 e 1982 permitem. Assim, no que concerne à relação entre "questões ou temas locais" e "avaliações de serviços públicos", de um lado, e preferência partidária e/ou intenção de voto, do outro, os dados das eleições de 1998 no Distrito Federal revelam uma situação de excepcionalidade. Este caráter excepcional refere-se às pesquisas realizadas, e não ao país, nem à sua história. Se construirmos matriz composta por áreas metropolitanas e anos, as pesquisas anteriores cobrem poucas áreas em poucos anos.

Situação de classe e organização das avaliações

$\mathrm{O}$ mito da irracionalidade às vezes é circunscrito aos analfabetos, às vezes refere-se, mais amplamente, aos eleitores menos educados. Em resposta à pergunta "como funciona a organização das crenças e avaliações do desempenho na cabeça dos eleitores?", vemos que há vários preconceitos de classe associados com visões estereotipadas a respeito dos eleitores menos instruídos, com menos educação formal. Um deles, o mais comum, supõe que a intenção de voto dos menos educados seja "menos racional". Este preconceito está presente tanto nos vanguardistas da esquerda quanto nos arautos do regime militar. A escolha política e eleitoral, dessa perspectiva, seria fundamentada em fatores personalistas e não em fatores racionais, derivados dos interesses dos eleitores. 
Os nossos dados mostram que não é assim: em cada um de cinco níveis educacionais encontramos altas correlações entre as avaliações do desempenho dos governadores em diferentes políticas públicas setoriais e a intenção de voto. ${ }^{20}$

\section{Tabela 5 \\ Coeficientes de correlação gama ordinal entre avaliações do desempenho e intenção de voto por nível educacional. Pesquisa Codeplan, 1998}

\begin{tabular}{lccccc}
\hline $\begin{array}{l}\text { Área } \\
\text { temática }\end{array}$ & Baixo & $\begin{array}{c}\text { Nível } \\
\text { Médio- } \\
\text { baixo }\end{array}$ & \multicolumn{3}{c}{ Médio } \\
Trânsito & 0,57 & 0,62 & 0,82 & 0,68 & 0,73 \\
Educação & 0,71 & 0,71 & 0,81 & 0,74 & 0,86 \\
Saneamento & 0,70 & 0,65 & 0,86 & 0,80 & 0,70 \\
Povo & 0,81 & 0,85 & 0,84 & 0,82 & 0,75 \\
Segurança & 0,70 & 0,70 & 0,80 & 0,80 & 0,68 \\
\hline
\end{tabular}

A Tabela 5 avança a nossa compreensão da racionalidade e da ideologia dos eleitores do Distrito Federal, ressaltando três aspectos:

- as avaliações do desempenho dos governadores em políticas públicas individualizadas apresentam altas correlações com a intenção de voto;

- em quatro áreas de avaliação - educação (uma das áreas em que Cristovam apresenta os seus melhores resultados); seguranca e saneamento (duas áreas intermediárias de avaliação) e "aproximação com o povo" (a área de melhor desempenho de Roriz) — as correlações são substanciais. Há um coeficiente abaixo de 60; quatro na casa dos 60, nove na casa dos 70 e onze na casa dos 80;

- as correlações são elevadas em todos os níveis educacionais. Não encontramos maior intimidade entre avaliações e intenção de voto nos níveis educacionais mais altos.

A magnitude destas correlações enterra o mito de que os brasileiros não "sabem votar", que exclui relações íntimas entre avaliações de políticas públicas e intenção de voto, e o preconceito de que só os mais instruídos sabem fazê-lo. Porém, dados menos "entusiasmados" com esta hipótese foram coletados por pesquisas cuidadosas realizadas durante o regime militar. Olavo Brasil de Lima Jr. (1978) utilizou testes de $X^{2}$ que mostram que, mesmo entre os 14 indicadores que Fábio Wanderley Reis chamou de "grandes questões", o número de associações significativas no nível de $10 \%$ era baixo, havendo uma diferença entre o eleitorado com alta escolarização $(57 \%$ das associações eram significativas) e aquele com baixa escolarização (30\% significativas). O que estes resultados sugerem? Mais uma vez, que os resultados da pesquisa no Distrito Federal diferem do conjunto clássico de pesquisas eleitorais efetuadas durante a ditadura, que gerou parte substancial do conhecimento sobre processos eleitorais no Brasil.

O efeito cumulativo das variáveis estruturais e das avaliações sobre a intenção de voto

No Distrito Federal, como em quase toda parte, o voto também é uma função da posição social. O que é inusitado é que, no Distrito Federal, os menos instruídos, que estão no fundo da pirâmide de estratificação, apoiaram o pré-candidato da direita, ao passo que os mais instruídos, cuja situação de classe é média ou alta, apoiaram o candidato da esquerda. A avaliação do desempenho das políticas públicas setoriais e a situação de classe influenciaram a intenção de voto cumulativamente: entre os que achavam que foi Cristovam quem fez mais pela educação, a percentagem dos que pretendiam votar nele cresceu com o nível educacional — de $42 \%$, entre os com mais baixo nível, para 56\%, entre os com nível médio-baixo; 66\%, no nível médio; 69\%, no nível médio-alto, atingindo $88 \%$ no nível alto -; entre os que achavam que quem fez mais pela educação não foi nem Cristovam nem Roriz ou deram outras respostas, a percentagem dos que pretendiam votar em Cristovam situou-se num patamar consideravelmente mais baixo, mas também cresceu com o nível educacional - 18\%,22\%, 27\%, 37\% e 47\%, respectivamente. Entre os que achavam que foi Roriz quem fez mais pela educação no Distrito Federal, as percentagens dadas a Cristovam eram muito baixas nos cinco níveis educacionais - 5\%, $10 \%, 10 \%, 14 \%$ e $14 \%$. 


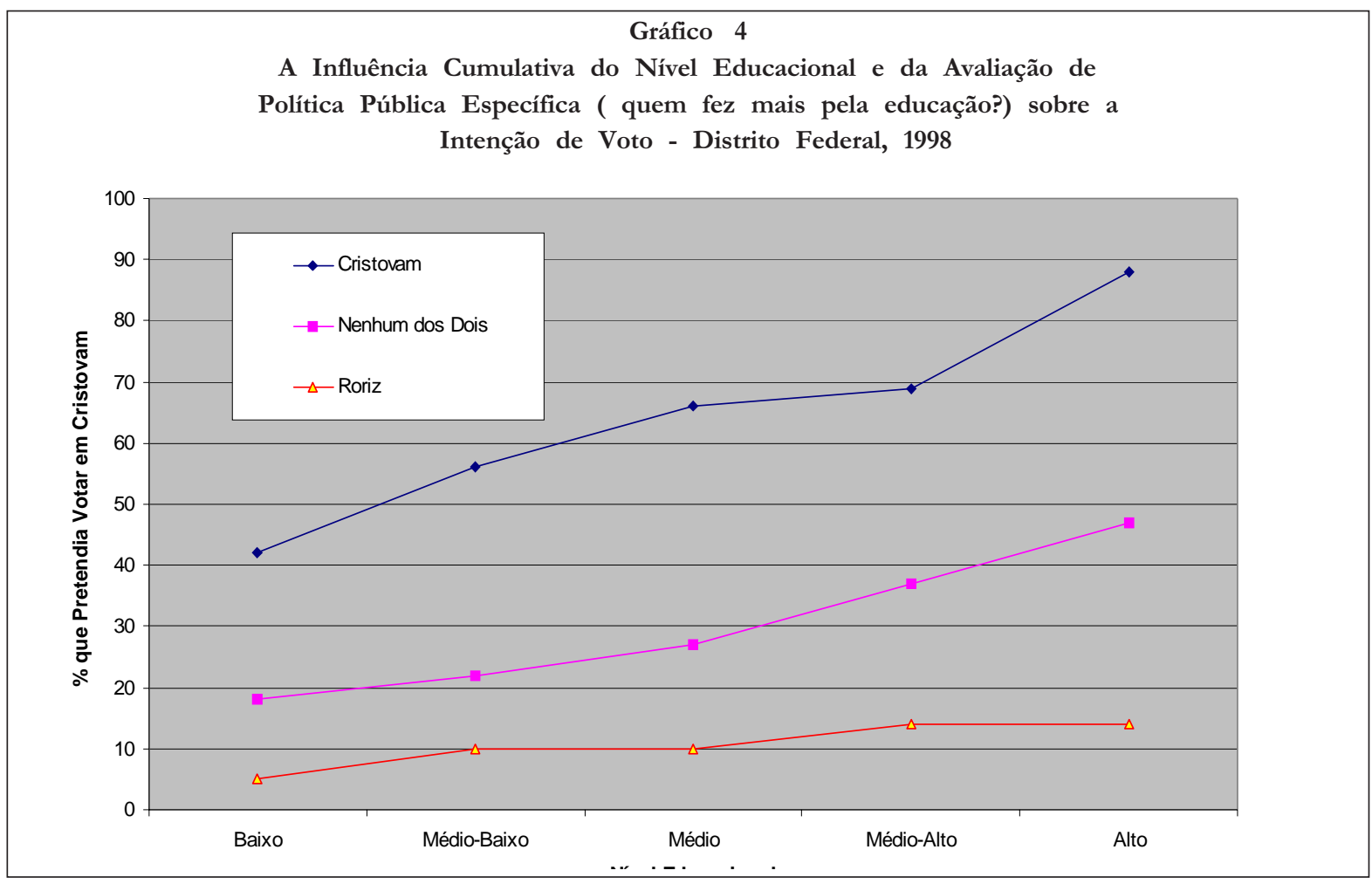

Conhecendo as avaliações do desempenho e a educação dos entrevistados, a capacidade de previsão dos votos que Cristovam obteria varia entre $5 \%$ (baixo nível educacional $e$ acha que Roriz fez mais pela educação) e $88 \%$ (alto nível educacional $e$ acha que Cristovam fez mais pela educação). Resultados semelhantes são obtidos quando substituímos a educação por outra área na qual a administração de Cristovam teve muito êxito, como o trânsito. Em todas as associações trivariatas que pesquisei, as duas variáveis explicativas, situação de classe e avaliação de política pública, influenciaram cumulativa e significativamente a intenção de voto.

\section{Regressão logística binomial}

A posição metodologicamente mais conservadora sugere que uma regressão logística é mais compatível com as propriedades dos dados do que uma linear. As regressões lineares seriam obtidas dicotomizando as respostas e criando uma variável dependente "dummy", seja Roriz/outras respostas ou Cristovam/outras respostas.
Iniciaremos as análises multivariatas com regressões logísticas binomiais, usando como variáveis dependentes duas dicotomias: Roriz/outras respostas ou Cristovam/outras respostas. Posteriormente, usaremos uma análise multinomial. Para completar, usaremos uma análise linear, cujos dados são apresentados no Apêndice ao final do artigo.

$\mathrm{Na}$ primeira regressão logística binominal, analisei a intenção de voto por Roriz, tomada como variável independente, recodificando as respostas como 1=Roriz e 2=Outras respostas. O modelo incluiu uma mistura de variáveis "atitudinais" (as avaliações das políticas públicas), pessoais (educação e tempo de residência no DF) e estruturais (Regiões Administrativas de residência, agrupadas de acordo com o nível socioeconômico - alto, médio e baixo - e reagrupadas de acordo com se derivaram de assentamentos ou não). ${ }^{21}$ Numa regressão "para trás", o tempo no DF foi a única variável eliminada. $\mathrm{O}$ modelo (sem o tempo de residência no DF) produziu um $X^{2}$ de 1.419,82 que, com sete graus de liberdade, é significativo no 
nível de 0,0000. O modelo, portanto, explica a intenção de voto por Roriz em níveis muito exigentes de significação.

O modelo permite acertar 79\% das respostas categóricas, sendo 63\% dos que responderam Roriz e $88 \%$ das outras respostas. Evidentemente, é satisfatório. A mistura de variáveis atitudinais, pessoais e estruturais demonstrou ser útil. O pseudo$R^{2}$, de Nagelkerke, de 0,47 é promissor.

Porém, esta resposta global não nos diz qual ou quais das variáveis incluídas na equação contribuem de forma estatisticamente significativa. Observando a estatística de Wald e a sua significação, vemos que:

- todas são estatisticamente significativas no nível de 0,0001 ou melhor;

- os escores fatoriais relativos às avaliações das políticas públicas têm, como na regressão linear, maior peso do que as variáveis estruturais.

\section{Regressão logística multinomial}

A utilização de análise logística multinomial revela o poder do modelo explicativo e os seus limites. No total, $57 \%$ dos casos foram corretamente classificados, o que, como esperado, representa uma clara perda em relação aos modelos binomiais. As alternativas mais difíceis de classificar são, via de regra, as com freqüência mais baixa. Seria necessário que uma das variáveis explicativas tivesse uma relação estreita com uma das alternativas, quase excluindo as demais. Não obstante, inexiste uma relação estreita entre peso na distribuição de freqüência e acerto na classificação. As “outras respostas", que podem ser consideradas como indicadoras de apatia, desinteresse, falta de informação política, naquele momento - vários meses antes das eleições - eram mais freqüentes do que as preferências por Cristovam, que, não obstante, recebeu maior número de classificações corretas; Arruda tinha a metade das preferências de Cristovam e, não obstante, foi muito difícil de classificar.

Roriz foi uma escolha explicada pelo modelo: $75 \%$ das opções foram corretamente classificadas, percentagem que cresce para $81 \%$ quando usamos um modelo binomial $e$ excluímos os desinteressados, apáticos etc. Duas de cada três (68\%) preferências por Cristovam foram corretamente previstas e $59 \%$ das "outras respostas" também o foram. O modelo é significativo num nível muito exigente. Porém, as variáveis que explicam uma alternativa não têm o mesmo peso nas demais alternativas.

Tabela 6

Resultados globais da regressão logística (Roriz/Outras respostas como dependente) escores fatoriais de avaliação de políticas públicas, variáveis pessoais e variáveis estruturais sobre a categorização de intenção de voto Roriz e outras respostas

Tabela de Classificação para Roriz - Valor do corte é 0,50

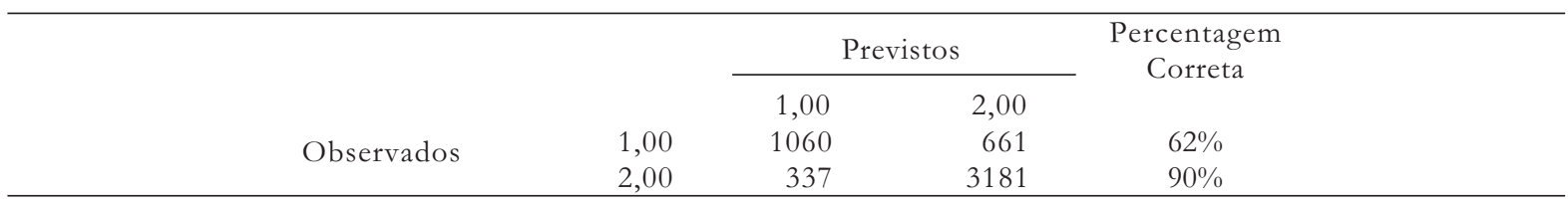

Total Correto $=81 \%$

Comportamento das Variáveis na Equação

\begin{tabular}{lrrrrrrr}
\hline Variável & B & S.E. & Wald & gl & Sig & R & Exp(B) \\
\hline Região Admin. &,- 1174 &, 0307 & 14,6323 & 1 &, 0001 &,- 0436 &, 8892 \\
Fator 2 &,- 4764 &, 0381 & 156,5993 & 1 &, 0000 &,- 1527 &, 6210 \\
Fator 1 & $-1,6440$ &, 0530 & 962,6050 & 1 &, 0000 &,- 3805 &, 1932 \\
Estudou &, 1082 &, 0200 & 29,1918 & 1 &, 0000 &, 0640 & 1,1143 \\
Novos assent. &, 3224 &, 0418 & 59,4105 & 1 &, 0000 &, 0930 & 1,3805 \\
Tempo no DF &,- 1486 &, 0245 & 36,6572 & 1 &, 0000 &,- 0723 \\
Constante &, 9396 &, 1614 & 33,8718 & 1 &, 0000 & \\
\hline
\end{tabular}


As variáveis que mais explicam a preferência por Roriz, de acordo com a estatística de Wald, seriam o Fator Geral de Avaliação das Políticas Públicas; o Fator 2; o nível educacional do entrevistado, e o fato de a pessoa morar ou não em uma RA que era um assentamento novo ou continha um assentamento novo. Já no que concerne a Cristovam, o Fator Geral de Avaliação das Políticas Públicas é, praticamente, o único que conta. $O$ nível socioeconômico da RA e a existência, dentro dela, de novos assentamentos não são significativos. Os principais determinantes das preferências por Arruda foram o Fator 2 e o nível educacional. O Fator Geral de Avaliação e o tempo de residência no DF são irrelevantes. As preferências por Augusto Carvalho eram explicadas pelo nível educacional, principalmente. Uma análise binomial das outras respostas sublinha a importância dos novos assentamentos e, secun- dariamente, do Fator 2. Todas as demais variáveis foram irrelevantes.

A conclusão é que a intenção de voto pelos principais candidatos — Roriz e Cristovam — nas eleições de 1998 no Distrito Federal foi função, sobretudo, da avaliação de políticas públicas feita pelo eleitorado.

Estes resultados contrastam, de maneira dramática, com os obtidos anteriormente em outras áreas metropolitanas brasileiras, particularmente os realizados durante a ditadura.

\section{Discussão final}

Como explicar essa discrepância? Proponho algumas possibilidades, que não são excludentes:

- Durante a ditadura militar, as "grandes questões", particularmente as políticas, como as chamou

Tabela 7

\begin{tabular}{|c|c|c|c|c|c|c|}
\hline \multirow[b]{3}{*}{ Observado } & \multicolumn{5}{|c|}{ Classificação } & \multirow[b]{3}{*}{$\%$ Correto } \\
\hline & \multicolumn{4}{|c|}{ Previsão } & \multirow{2}{*}{$\begin{array}{l}\text { Outras } \\
\text { respostas }\end{array}$} & \\
\hline & Roriz & Arruda & Cristovam & Carvalho & & \\
\hline Roriz & 1106 & 1 & 84 & 0 & 280 & $75.2 \%$ \\
\hline Arruda & 177 & 4 & 130 & 0 & 236 & $.7 \%$ \\
\hline Cristovam & 80 & 4 & 678 & 0 & 238 & $67.8 \%$ \\
\hline Carvalho & 21 & 5 & 37 & 0 & 84 & $.0 \%$ \\
\hline Outras respostas & 328 & 9 & 200 & 0 & 771 & $58.9 \%$ \\
\hline Total & $38.3 \%$ & $.5 \%$ & $25.2 \%$ & $.0 \%$ & $36.0 \%$ & $57.2 \%$ \\
\hline
\end{tabular}

\begin{tabular}{lrrr}
\hline Modelo & -2 Log & Chi-Quadrado & gl Sig. \\
& Verossimilhança & & \\
\hline Intercepto & 12600.491 & & \\
Final & 9778.714 & 2821.777 & 24.000 \\
\hline
\end{tabular}

\begin{tabular}{|c|c|c|c|c|}
\hline Efeito & $\begin{array}{c}-2 \text { Log Verossimilhança } \\
\text { do Modelo Reduzido }\end{array}$ & $\mathrm{X}^{2}$ & Gl. & Sig. \\
\hline Intercepto & $7.282,712$ & 0,000 & 0 & \\
\hline Tempo de residência no DF & $7.294,625$ & 11,913 & 4 & 0,018 \\
\hline Nível socioeconômico da RA & $7.314,336$ & 31,624 & 4 & 0,000 \\
\hline Nível educaional & $7.381,911$ & 99,199 & 4 & 0,000 \\
\hline Fator 2 & $7.354,657$ & 71,945 & 4 & 0,000 \\
\hline Fator 1 & $8.783,351$ & $1.500,639$ & 4 & 0,000 \\
\hline Novos assentamentos & $7.390,517$ & 107,805 & 8 & 0,000 \\
\hline
\end{tabular}


Fábio Wanderley Reis, adquiriram saliência e prioridade indiscutíveis. O que estava na cabeça de todo democrata brasileiro era sair da ditadura. Os temas econômicos que o regime usou, durante o período do "milagre", como autojustificação ficaram em segundo lugar e os temas locais não adquiriram relevância eleitoral. As campanhas eram feitas sempre em relação à ditadura. Alguns dos temas políticos importantes da época não fazem sentido hoje, após a volta à democracia: acabar ou não com o AI-5, pedra jurídica central da ditadura, e com a Lei Falcão, orientada para impedir o efeito da mídia nas eleições, deixou de ser relevante após sua abolição.

- A função das eleições difere. Durante a ditadura militar, o peso dado à possibilidade de implementar ou mudar políticas públicas através de eleições era pequeno. Os loci de poder não estavam na sociedade civil e nas suas instituições políticas, mas no estabelecimento militar e nas instituições de governo que os militares controlavam. A grande função das eleições era simbólica expressão da rejeição ao regime;

- A Constituição de 1988 descentralizou efetivamente os recursos públicos. Governadores e prefeitos tiveram mais recursos à mão para implementar políticas, para "fazer";22

- Durante a ditadura militar, a confiabilidade das pesquisas de opinião era mais baixa. Podemos advertir o efeito da repressão no rápido descenso das preferências e dos votos para o PDS, partido da ditadura, já durante a abertura e depois, após a redemocratização. O descenso foi clamorosamente visível na campanha das Diretas-Já, que acelerou o fim da ditadura, quando a percentagem favorável à eleição direta do presidente da República subiu vertiginosamente em poucos meses. Não sabemos se subiu mesmo ou se a aprovação que já existia foi expressada por fatias cada vez maiores dos eleitores. Da mesma forma, a permanência dos militares no poder era questão extremamente sensível. Os dados da época mostram que entre metade e três quartas partes da população respondiam que os militares deveriam permanecer. Era um sentimento autêntico, generalizado, ou uma resposta prudente, conveniente? Nos últimos anos, a percentagem dos que gostariam de voltar ao regime militar tem oscilado entre $15 \%$ e $25 \%$. Não tenho dúvidas de que a parte da população que favorece a de- mocracia cresce à medida que ela se estabelece e dá frutos, mas também não tenho dúvidas de que a repressão foi um fator importante na determinação da artificialidade de muitas respostas. Entender estas diferenças classificando o período democrático como "normal" e o anterior como repressivo, provocando respostas falsas ou, simplesmente, ver todo e qualquer regime como um sistema de coações sociais e políticas, sendo uns mais coercitivos e outros menos, é, evidente, uma questão de preferência pessoal. Lembro apenas que, se bem é verdade que toda sociedade e seus subgrupos exercem pressões na direção da conformidade, nos regimes não-democráticos a pressão é política e policial e o preço a pagar pela nãoconformidade é muito maior;

- O fim da ditadura diminuiu a relevância das grandes questões políticas. Após a redemocratização, as contínuas mudanças no quadro institucional-partidário roubaram algo da relevância que Arena e MDB tinham. Creio que a identificação partidária perdeu poder de influenciar o voto, mas também creio que este poder poderá ser recuperado com a estabilidade e certa simplificação institucional-partidária;

- Com a diminuição das "grandes questões políticas" e a perda de poder da identificação partidária, além do fim da "guerra fria", reduzindo o peso das grandes questões ideológicas, cresceu, num modelo que soma zero, a significação da política do "feijão-com-arroz";

- Brasília pode ser uma região excepcional no Brasil, devido a seus altos níveis de renda e de educação, a depender pesadamente do governo federal, e à importância das migrações recentes e de peculiaridades como os assentamentos urbanos;

- O governador Cristovam Buarque fez uma campanha baseada no seu desempenho, nos seus programas, enfatizando as políticas públicas e os benefícios para a população. Paz no trânsito; Bolsa-escola; Saúde em casa; Paz nas muas e Orçamento participativo eram expressões corriqueiras na mídia e nas conversas de rua;

- Os principais candidatos — os que foram para o segundo turno - eram o governador e um ex-governador. Isto torna possível a comparação entre o desempenho e as políticas públicas dos dois. 
Foi graças à série de pesquisas coordenada por vários dos melhores cientistas políticos brasileiros e parcialmente financiada pela Fundação Ford que acumulamos boa parte do conhecimento hoje disponível sobre os processos políticos e eleitorais durante o regime militar. Alguns destes resultados levaram analistas leigos à conclusão apressada de que o brasileiro não sabe votar, de que a cultura cívica e política brasileira é, de alguma maneira, inferior, pré-democrática. Seríamos politicamente irracionais. Creio, porém, que perdendo ou ganhando as eleições, não há como abandonar a racionalidade como fator explicativo do voto. Evidentemente, há mais de uma prioridade para as diversas "racionalidades". A pesquisa pré-eleitoral de 1998 no Distrito Federal demonstra a existência dessa racionalidade e sugere a presença de fortes efeitos contextuais e institucionais para explicar as diferenças entre as suas conclusões e a herança cognitivo-empírica que a informou. Está na hora de realizarmos uma pesquisa eleitoral desligada das eleições objetivando colocar alguns controles contextuais e institucionais no questionário e, também, reestudar a ditadura, agora num contexto livre, democrático.

\section{Apêndice: regressões lineares}

Efetuei regressões lineares, a despeito das limitações dos dados. Os objetivos desta análise eram:

- ver qual o poder explicativo de um modelo que, usando dados de survey, procurava integrar dados de avaliações com dados individuais e estruturais;

- verificar até que ponto a intenção de voto dependia da avaliação comparada das políticas públicas, independentemente de variáveis individuais e estruturais;

- verificar qual o peso relativo de cada grupo de variáveis na explicação da intenção de voto.

Incluí as variáveis presentes nas regressões logísticas, adicionando uma variável interativa, que procurava avaliar o impacto da condição de migrantes recentes vivendo em assentamentos criados por Roriz. Nesta análise, usei como variável dependente a intenção de voto com três categorias: $1=$ Cristovam; $2=$ Outras respostas e $3=$ Roriz. $^{23}$ Este modelo demonstrou ampla utilidade, com uma correlação múltipla de 0,66 e um $R^{2}$ ajustado de 0,43. O modelo é significativo no nível de 0,000. Estes resultados qualificam o modelo como altamente satisfatório, considerando o valor de $R^{2}$, a significação estatística e a experiência com dados de survey, onde $R^{2}$ desta magnitude são pouco freqüentes. ${ }^{24}$

A análise do "Rorizismo" foi efetuada com nova recodificação, usando somente as categorias Roriz/Outras respostas. Uma eliminação "para trás" retira tanto o tempo de residência no Distrito Federal quanto a sua interação com o fato de a RA ter ou ser um assentamento recente. Este modelo tem um $R^{2}$ ajustado de 0,33 , alto para este tipo de dados.

Tabela 8

Regressão linear

Modelo com variáveis atitudinais (avaliações de políticas públicas), pessoais e estruturais com Roriz/Outras respostas como variável dependente

\begin{tabular}{|c|c|c|c|c|c|}
\hline Modelo & $\begin{array}{c}\text { Beta } \\
\text { Padronizado }\end{array}$ & $\mathrm{t}$ & $\mathrm{P}$ & $\begin{array}{l}\text { Correlação } \\
\text { ordem zero }\end{array}$ & $\begin{array}{c}\text { Correlação } \\
\text { Parcial }\end{array}$ \\
\hline Constante & & 40,106 & 0,000 & & \\
\hline $\begin{array}{l}\text { Assentamento Criado? } \\
1=\operatorname{sim} 2=\text { outras } 3=\text { não }\end{array}$ & 0,071 & 4,839 & 0,000 & 0,211 & 0,083 \\
\hline Escolaridade (1 a 6, 1 é baixa) & 0,096 & 6,093 & 0,000 & 0,270 & 0,104 \\
\hline Avaliação Fator 1 (alto é pró-Roriz) & $-0,493$ & $-33,510$ & 0,000 & $-0,546$ & $-0,499$ \\
\hline Avaliação Fator 2 (alto é pró-Roriz) & $-0,088$ & $-6,266$ & 0,000 & $-0,092$ & $-0,107$ \\
\hline Nível SE da RA (Alto, Médio, Baixo) & $-0,070$ & $-4,540$ & 0,000 & $-0,224$ & $-0,078$ \\
\hline
\end{tabular}


No que concerne ao impacto relativo da avaliação comparada das políticas públicas, o instrumento mais adequado, neste tipo de regressão (linear), é o coeficiente padronizado Beta. A padronização é necessária porque as variáveis independentes têm escalas, desvios padrões e médias muito diferentes. O Fator 1, de avaliação comparada das políticas públicas, é, de longe, a variável mais importante na determinação da intenção de voto, com um coeficiente Beta mais de cinco vežes mais alto que o segundo, que também é um escore fatorial (Fator 2) derivado da análise de componentes principais das avaliações comparadas.

As demais variáveis se comportaram de acordo com a expectativa dos analistas políticos locais: a intenção de voto para Roriz aumenta se a Região Administrativa foi criada como assentamento, e correlaciona-se negativamente com a escolaridade e com o nível socioeconômico da Região Administrativa.

A análise de correlações mostra que o Fator 1 é pouco afetado pela passagem de correlações de ordem zero para correlações parciais, entre resíduos (0,55 para -0,50); o Fator 2 é ajudado por esta passagem e as demais variáveis perdem parte do poder de explicação. Há necessidade de atenção na direção da codificação das variáveis (considerando que Roriz=0 e não-Roriz=1): a educação foi codificada de menor para maior; conseqüentemente, correlaciona-se positivamente com a intenção de voto não-Roriz; já o nível socioeconômico dos assentamentos foi codificado do maior para o menor, correlacionando-se negativamente com a intenção de voto não-Roriz.

\section{NOTAS}

1 Por ordem decrescente das correlações: diminuir a violência; diminuir a corrupção; criar empregos; melhorar o atendimento médico e oferecer casa própria. Aumentar o salário dos que ganham pouco, fazer crescer a economia e diminuir a inflação não tinham correlações significativas com a intenção de voto para Quércia.

2 Esta concepção de que "o brasileiro não sabe votar" (mas a cidadania dos países desenvolvidos saberia...) está tão arraigada que poucos se deram ao trabalho de justificá-la ou de examiná-la.
3 No momento da pesquisa havia pré-candidatos, não candidatos. Dos quatro pré-candidatos, um, Augusto Carvalho, desistiu da candidatura ao governo do Distrito Federal; Cristovam obteve 3\% a mais de votos do que Roriz no primeiro turno, mas foi derrotado no segundo.

4 A lista da Companhia de Eletricidade de Brasília é a mais satisfatória, dado o fato de que a quase totalidade da população está ligada ao sistema.

5 Uma precaução necessária, dada a alta taxa de migrações para Brasília e a ativa fronteira com Goiás e Minas Gerais.

6 A necessidade desta explicaçação deve-se a judiciosas críticas metodológicas de Yuri Suárez Dillon Soares.

7 Além de servirem de guias eleitorais, o conhecimento das avaliações do desempenho dos governadores atuais ou passados - é um instrumento de governo. Elas revelam quais as áreas comparativamente fortes $\mathrm{e}$ quais as áreas comparativamente fracas, de acordo com a opinião pública. As crenças, as avaliações setoriais do desempenho e a percepção de áreas de maior necessidade são mais estáveis do que a intenção de voto e revelam necessidades e prioridades da população. Devemos distinguir entre democracia eleitoral e democracia no governo (democracy in governance). Ser eleito democraticamente é uma coisa; governar democraticamente é outra. Usar surveys para impedir que se abra um fosso entre o governo e a população é prática comum nos países centrais.

8 Coloco teoria entre aspas porque afirmações feitas por líderes políticos conservadores, sobretudo durante o regime militar, e a existência de minoria significativa da população que concorda, nos surveys, com essa afirmação não bastam para configurar uma teoria.

9 A "intuição", baseada no Iluminismo, sugere que a complexidade da plataforma cresceria com o nível educacional. Os dados não apóiam esta posição.

10 Infelizmente, o governador Roriz desativou ou descaracterizou os programas do governo anterior, inclusive alguns que beneficiavam muito a população, como o Bolsa-Escola, o Paz no Trânsito, o Paz nas Ruas e o Saúde em Casa.

11 Em contraste, três em cada quatro $(76 \%)$ da minoria que achava que Roriz foi quem mais diminuiu a violência no trânsito votariam nele, $7 \%$ em Arruda e 5\% em Cristovam.

12 A denominação talvez seja politicamente incorreta: a preferida por alguns estudiosos e ativistas é "ocupante".

13 Coloco teoria entre aspas porque é mais uma atitude do que uma teoria coerente, elaborada. Os seus proponentes tampouco se preocuparam em "testá-la", ou "falsificá-la", limitando-se a afirmá-la.

14 Erroneamente visto como um atributo pessoal do candidato e não como uma relação entre estes atributos e setores do eleitorado.

15 Sabe-se lá o que significa isso. 
16 Obviamente, tal qual percebidos pelos próprios eleitores e não pelos analistas políticos e/ou dirigentes partidários.

17 Embora a inspeção visual do gráfico sugira uma sinuosidade, e a solução polinomial de terceiro grau nos dê um $R^{2}$ de 0,99 , a solução linear, mais simples e elegante, é preferível. Dois por cento de perda da explicação da variância é uma perda pequena, mais do que compensada pela simplificação da teoria.

18 Com várias ou muitas observações, dificilmente as soluções polinomiais deixarão de proporcionar coeficientes de determinação mais elevados do que as lineares. Isto não justifica o uso indiscriminado de soluções polinomiais, o que poderíamos chamar de "brincar de polinômio", perigo real para os que se concentram exclusivamente na variância explicada. A diferença entre as variancias explicadas tem de ser, ela própria, estatisticamente significativa e o pesquisador tem de justificar teoricamente a opção polinomial.

19 Aqui também o ganho com as soluções polinomais é pequeno, o que nos leva a ficar com a solução linear, mais simples e elegante.

20 Foram usados vários coeficientes, tanto nominais, quanto ordinais. Reportamos os gama ordinais.

21 A inserção de dados estruturais como atributos individuais enviesa as estimativas porque dá ao indivíduo um valor médio que pode não ser $\mathrm{o}$ dele. $\mathrm{O}$ efeito esperado dessa inadequação é piorar as estimativas, aumentando o erro.

22 Infelizmente, esses recursos adicionais foram rapidamente comprometidos com o pagamento do pessoal ativo e inativo.

23 O leitor metodologicamente sofisticado perceberá que o uso de regressões lineares com este tipo de dados não é "conservador", porque supõe um poder de mensuração que algumas das variáveis do modelo não oferecem.

24 Regressões raramente são usadas nas ciências políticas e sociais no Brasil. Von Mettenheim (1995, p. 176) usou a avaliação do desempenho do Executivo, a percepção de políticas sociais e a percepção de políticas econômicas num modelo cujo poder explicativo se expressou num $R^{2}$ ajustado de 0,17 .

\section{BIBLIOGRAFIA}

AVELAR, Lúcia. (1989), O segundo eleitorado. Campinas, Ed. da Unicamp.

FERREIRA, Adir Luiz e SOUSA, Margarete F. Vale. (1996), "A democracia brasileira numa cultura política estudantil", in Marcello Baquero (org.), Condicionantes da consolidação democrática: ética, mídia e cultura política, Porto Alegre, Editora da Universidade Federal do Rio Grande do Sul.
LAMOUNIER, Bolivar. (1978), "Presidente Prudente: o crescimento da oposição num reduto arenista", in Fábio Wanderley Reis (org.), Os partidos e o regime, São Paulo, Símbolo.

LIMA JUNIOR, Olavo Brasil de. (1978), “Articulação de interesses, posição socioeconômica e ideologia: as eleições de 1976 em Niterói”, in Fábio Wanderley Reis (org.), Os partidos e o regime, São Paulo, Símbolo.

MOISÉS, José Álvaro. (1993), "Democratization and political culture", in Maria D'Alva G. Kinzo (org.), Brazil: the challenges of the 1990's, Londres, The Institute of Latin American Studies, The University of London.

MUSZYNSKI, Maria Judith de Brito. (1986), “Os eleitores paulistanos em 1986: a marca do oposicionismo", in Maria Tereza Sadek et al., Eleições — 1986, São Paulo, Vértice/Idesp.

REIS, Fábio Wanderley. (1978), “Classe social e opção partidária: as eleições de 1976 em Juiz de Fora", in Fábio Wanderley Reis (org.), Os partidos e o regime, São Paulo, Símbolo.

TRINDADE, Hélgio e CEW, Judson de. (1978), “Confrontação política e decisão eleitoral: as eleições municipais de 1976 em Caxias do Sul”, in Fábio Wanderley Reis (org.), Os partidos e o regime, São Paulo, Símbolo.

VON METTENHEIM. (1995), The Brazilian voter. Pittsburgh, University of Pittsburgh Press. 